\title{
SONOGRAPHIC IMAGING AND CYTOLOGICAL CHANGES IN THYROID IN PATIENTS WITH BREAST CARCINOMA
}

\author{
Manisha Shrestha, ${ }^{1}$ Dipak Paruliya, ${ }^{2}$ Anand Kumar ${ }^{3}$
}

\section{ABSTRACT}

\section{INTRODUCTION}

The association between thyroid disorders and breast cancer is debated. A possible relationship between breast carcinoma and thyroid disorders have been suggested considering the fact that the breast malignancy may alter endocrine homeostasis. A prospective cross sectional study in breast cancer patients was performed to evaluate the association of breast cancer with thyroid disorders. Ultrasonography and cytological changes in thyroid gland were evaluated.

\section{MATERIAL AND METHODS}

The study included 30 consecutive newly diagnosed breast cancer patients between the age group of 30 to 60 years. The study had a control group of 20 age matched patients from the same geographical area with no breast or thyroid disease and no malignancy. The presence of thyroid disease was examined by using well defined diagnostic criteria of ultrasonography. The observations on ultrasound were correlated with cytological assessment in breast cancer patients only.

\section{RESULTS}

Results were analyzed statistically by Fischer's exact probability test, Pearson correlation coefficient and unpaired student ' $\mathrm{T}$ ' test. Sonographically nodular thyroid was observed in $50 \%$ of breast cancer patients as compared to $10 \%$ in control group $(\mathrm{p}<0.002)$. Majority of patients had solitary and solid echo texture thyroid nodules. There was a direct correlation between the stage of breast cancer and total thyroid volume. All thyroid nodules were cytologically benign (adenomatous/ colloid nodular goiter) on cytological evaluation.

\section{CONCLUSION}

It is concluded that an increased preponderance of thyroid disorders exist in patients with breast cancer.

KEYWORDS Ultrasonography, cytology, thyroid, breast carcinoma

1. Department of Pathology, Universal College of Medical Sciences, Bhairahawa, Nepal

2. Department of Surgery, Institute of Medical Sciences, Banaras Hindu University, Varanasi, India

3. Department of Surgery, Universal College of Medical Sciences, Bhairahawa, Nepal

DOI: https://doi.org/10.3126/jucms.v6i2.22503

\author{
For Correspondence: \\ Dr. Manisha Shrestha \\ Department of Pathology \\ Universal College of Medical Sciences \\ Bhairahawa, Nepal. \\ Email:mansha.stha@gmail.com
}




\section{INTRODUCTION}

Breast cancer is a hormone dependent neoplasm which may alter the endocrine homeostasis in the body. The association of thyroid diseases and breast carcinoma has been debated since long. Nodular thyroid hyperplasia, autoimmune thyroid disease, hypothyroidism, hyperthyroidism and thyroid cancer have been reported in patients with breast carcinoma. ${ }^{1-6}$

An increase in breast cancer incidence has been reported in areas with endemic goiter, contrary to this incidence no change has occurred after iodine prophylaxis. ${ }^{1}$ Also, increased breast cancer mortality was reported by Goldman et $\mathrm{al}^{3}$ in patients who had nontoxic nodular goiter and were receiving $\mathrm{T}_{4}$ suppression therapy. Thus, the significance of the simultaneous occurrence of thyroid disease and breast cancer remains to be elucidated.

The present prospective study was done to evaluate the prevalence of thyroid disorders in Indian women with breast cancer by using ultrasonography (USG) and fine needle aspiration cytology (FNAC).

\section{MATERIAL AND METHODS}

This study is a prospective cross sectional study carried out in the Department of Surgery, Institute of Medical Sciences, Banaras Hindu University over a period of 2 years. Ethical clearance for the study was taken by the third author from institutional review board of Banaras Hindu University as a principal investigator. After taking formal consent from the patients, the study enrolled 30 consecutive newly diagnosed female breast carcinoma patients (study group) who were evaluated during the preoperative period before starting any chemotherapy, hormonal therapy, surgery or radiotherapy.

The study also included a control group of 20 age matched women without any breast, thyroid disorder or any malignancy who were admitted within the same period in the surgical unit for treatment of various benign diseases, other than those of the breast and thyroid. Patients who had previous history of thyroid surgery or received therapy for any known thyroid disease were excluded from the study.

All patients from both groups were systematically evaluated according to the following protocol:

1. Clinical palpation of thyroid gland.

2. Ultrasonographic evaluation of thyroid gland by the same radiologist every time. Thyroid ultrasound scans were performed using a scanner having 7.5 MHz linear transducer (LOGIQ 400 CL, General Electrical Medical System, Tokyo, Japan). The volume of each lobe was calculated by using the
Brown and Spencer ${ }^{7}$ formula: Length $\mathrm{x}$ Width $\mathrm{x}$ Height $\mathrm{x} \pi / 6$. The patients were classified on the basis of clinical and ultrasound examination into those with normal thyroid, diffuse goiter, solitary nodule or multiple nodules.

3. USG guided fine needle aspiration (FNA) of the thyroid nodule was performed only in breast cancer patients with USG detected thyroid nodule. Control group patients did not undergo FNAC. The aspiration was performed with a $23 \mathrm{G}$ needle and smears fixed in absolute alcohol were stained by Papanicoloau stain and air dried smears were stained with hematoxylin and eosin stain (H\&E stain). All smears were examined by the same experienced pathologist every time.

The data were expressed as their mean values (range). Results were analyzed by Fischer's exact probability test, Pearson correlation coefficient and unpaired student ' $\mathrm{T}$ ' test. $\mathrm{P}<0.05$ was considered to be statistically significant. SPSS Statistics version 23 was used for data analysis.

\section{RESULTS}

The study group included 30 female patients with newly diagnosed breast carcinoma. The age range of the patients were from 30-60 years with mean age of 43.4 years. Twentyfive cases had invasive ductal carcinoma followed by one case each of invasive lobular carcinoma, medullary carcinoma, papillary carcinoma, small cell carcinoma and squamous cell carcinoma (Table 1).

Table 1. Distribution of study group cases according to histological types of breast cancer

\begin{tabular}{|l|c|c|}
\hline $\begin{array}{l}\text { Histological } \\
\text { type of carcinoma }\end{array}$ & $\begin{array}{c}\text { Study Group } \\
\text { n (\%) }\end{array}$ & $\begin{array}{c}\text { Study group with } \\
\text { thyroid nodule } \\
\text { n (\%) }\end{array}$ \\
\hline Invasive ductal & $25(83.3)$ & $14(93.3)$ \\
Invasive lobular & $1(3.3)$ & $1(6.66)$ \\
Squamous cell & $1(3.3)$ & \\
Small cell Ca & $1(3.3)$ & \\
Medullary Ca & $1(3.3)$ & \\
Papillary Ca & $1(3.3)$ & \\
\hline Total & $30(100)$ & $15(100)$ \\
\hline
\end{tabular}

Out of the total 30 study group cases, USG evaluation showed nodular thyroid in $15(50 \%)$ cases, among which 2 cases had clinically palpable thyroid. Nine $(60 \% ; n=15)$ cases had solitary nodule in left lobe of thyroid, while remaining 6(40\%; $\mathrm{n}=15$ ) cases had multiple nodules in both lobes of thyroid (Table 2). 
Table 2. Distribution of cases according to sonographic findings of thyroid

\begin{tabular}{|l|c|c|c|}
\hline Sonographic findings & $\begin{array}{c}\text { Study group } \\
\mathbf{n}(\mathbf{\%})\end{array}$ & $\begin{array}{c}\text { Control Group } \\
\mathbf{n} \mathbf{( \% )}\end{array}$ & \\
\hline Normal thyroid & $15(50)$ & $18(90)$ & \\
Nodular thyroid & $15(50)$ & $2(10)$ & $(\mathrm{p}<0.002)$ \\
$\quad$ Solitary nodule & 9 & 2 & \\
Multiple nodules* & 6 & - & \\
\hline Total & $30(100)$ & $20(100)$ & \\
\hline
\end{tabular}

*2 cases had clinically palpable thyromegaly

Majority of study group cases $(66.6 \% ; n=10 / 15)$ had 5-10 mm sized thyroid nodules and $5(33.3 \% ; n=15)$ cases had thyroid nodules more than $10 \mathrm{~mm}$ in size. Most thyroid nodules $(66.6 \% ; n=10 / 15)$ were solid hypoechoic or hypo-isoechoic on USG (Table 3$)$.

Table 3. Distribution of study group cases with thyroid nodules according to USG findings and corresponding cytological diagnosis

\begin{tabular}{|c|c|c|c|c|}
\hline \multirow[b]{2}{*}{ USG findings } & \multirow[b]{2}{*}{$\begin{array}{c}\text { Frequency } \\
\text { n (\%) }\end{array}$} & \multicolumn{3}{|c|}{ FNAC } \\
\hline & & $\begin{array}{c}\text { Benign } \\
\text { (n) }\end{array}$ & $\begin{array}{c}\text { Malignant } \\
\text { (n) }\end{array}$ & $\begin{array}{c}\text { Inadequate } \\
\text { material } \\
(\mathbf{n})\end{array}$ \\
\hline Total & $15(100)$ & $13\left(10^{*}+3^{+}\right)$ & 0 & 2 \\
\hline $\begin{array}{l}\text { Echo texture } \\
\text { Solid } \\
\text { Mixed } \\
\text { Cystic } \\
\end{array}$ & $\begin{array}{c}10(66.6) \\
4(26.6) \\
1(6.6)\end{array}$ & $\begin{array}{l}9\left(7^{*++} 2^{+}\right) \\
4\left(3^{*+} 1^{+}\right)\end{array}$ & 0 & $\begin{array}{l}1 \\
- \\
1\end{array}$ \\
\hline $\begin{array}{c}\text { Echogenicity } \\
\text { Hypoechoic } \\
\text { Hypo-isoechoic } \\
\text { Mixed echoic } \\
\text { Anechoic } \\
\end{array}$ & $\begin{array}{c}6(40) \\
4(26.6) \\
4(26.6) \\
1(6.6) \\
\end{array}$ & $\begin{array}{c}6\left(4^{*+}+2^{+}\right) \\
3\left(2^{*+1} 1^{+}\right) \\
4\left(4^{*}\right) \\
-\end{array}$ & 0 & $\begin{array}{l}- \\
1 \\
- \\
1\end{array}$ \\
\hline $\begin{array}{l}\text { Nodule margins } \\
\text { Well defined } \\
\text { ill defined } \\
\end{array}$ & $\begin{array}{l}9(60) \\
6(40) \\
\end{array}$ & $\begin{array}{l}7\left(5^{*+}+2^{+}\right) \\
6\left(5^{*+1} 1^{+}\right) \\
\end{array}$ & 0 & $\begin{array}{l}2 \\
- \\
\end{array}$ \\
\hline $\begin{array}{c}\text { Calcification } \\
\text { Present } \\
\text { Absent } \\
\end{array}$ & $\begin{array}{c}5(33.3) \\
10(66.6)\end{array}$ & $\begin{array}{c}5\left(5^{*}\right) \\
8\left(5^{*+}+3^{+}\right) \\
\end{array}$ & 0 & $\overline{2}$ \\
\hline
\end{tabular}

* Adenomatous nodular goiter + Colloid nodule

Control Group: Two (10\%) patients out of 20 patients from control group had thyroid nodules on USG evaluation. (Table 2) Both cases had solitary nodule in the left thyroid lobe, one was anechoic (cystic) and the other one was of mixed echo texture on USG.

The total thyroid volume in study group patients ranged from $5.541 .8 \mathrm{ml}$ with a mean volume of $10.64 \pm 1.56 \mathrm{ml}$ (mean \pm SD) as compared to the total thyroid volume in the control group which ranged from $5.013 .1 \mathrm{ml}$ with a mean volume of $8.01 \pm 1.79 \mathrm{ml}($ mean $\pm \mathrm{SD})$. However, the difference of total thyroid volume in between the study group and control group was statistically not significant (Table 4). The total thyroid volume showed an increase with the stage of breast carcinoma, however it was not statistically significant $(\mathrm{p}=0.1)$ (Table 5).

Table 4. Distribution of cases according to thyroid volume

\begin{tabular}{|c|c|c|c|}
\hline Thyroid volume & $\begin{array}{c}\text { Study Group } \\
\text { n (\%) }\end{array}$ & $\begin{array}{c}\text { Control Group } \\
\text { n (\%) }\end{array}$ & \\
\hline$<5 \mathrm{ml}$ & - & $1(5)$ & \\
\cline { 1 - 2 }$>5 \mathrm{ml}-10 \mathrm{ml}$ & $23(76.6)$ & $13(65)$ & \multirow{2}{*}{$\mathrm{p}=0.1$} \\
\hline$>10-15 \mathrm{ml}$ & $4(13.3)$ & $6(30)$ & \\
\hline$>15-20 \mathrm{ml}$ & $1(3.3)$ & - & \\
\hline$>20 \mathrm{ml}$ & $2(6.6)$ & - & \\
\hline Total & $30(100)$ & $20(100)$ & \\
\hline
\end{tabular}

Table 5. Distribution of breast cancer patients according to the total thyroid volume and stage of breast cancer

\begin{tabular}{|c|c|c|c|c|}
\hline $\begin{array}{c}\text { Stage of } \\
\text { Breast Cancer }\end{array}$ & $\begin{array}{c}\text { Frequency } \\
\text { n (\%) }\end{array}$ & $\begin{array}{c}\text { Mean thyroid } \\
\text { volume (mI) } \\
\text { (Mean } \pm \text { SD) }\end{array}$ & $\begin{array}{c}\text { Cases with } \\
\text { thyroid nodule } \\
\text { n (\%) }\end{array}$ & \\
\hline II a & $1(3.3)$ & 6.4 & - & \\
\cline { 1 - 4 } II b & $2(6.6)$ & $5.85 \pm 0.49$ & $1(6.6)$ & \multirow{2}{*}{$\mathrm{p}=0.1$} \\
\hline III a & $3(10)$ & $7.23 \pm 1.09$ & $2(13.3)$ & \\
\hline III b & $18(60)$ & $11.23 \pm 7.89$ & $9(60)$ & \\
\cline { 1 - 4 } IV & $6(20)$ & $12.9 \pm 8.71$ & $3(20)$ & \\
\hline Total & $30(100)$ & $10.6 \pm 8.56$ & $15(100)$ & \\
\hline
\end{tabular}

USG guided FNA was done in 15 study group cases with thyroid nodules and cytological evaluation revealed 13 cases $(86.6 \% ; n=15)$ had benign thyroid nodular disease with 10 $(66.6 \% ; n=15)$ cases of adenomatous nodular goiters and 3 $(20 \% ; n=15)$ cases of colloid nodules and remaining $2(13.3 \%$; $n=15)$ cases had inadequate cellular material. None of the patients showed malignant pathology on cytological examination of the thyroid nodule (Table 3 ).

\section{DISCUSSION}

The relationship between breast cancer and thyroid diseases has long been a matter of discussion. It was Beatson ${ }^{8}$ who first described in the Lancet in 1896 using thyroid extracts to treat patients with metastatic breast carcinoma and since then many studies have described an association between breast cancer and thyroid disorders. However, there have also been many reports that do not confirm this association., ${ }^{9,10}$

Evidence in support of this association are data showing geographical variations in the incidence of breast cancer attributing to differences in dietary iodine intake. ${ }^{11}$ The increased prevalence of fibrocystic disease in women living in endemic iodine deficient areas and the experimental appearance of mammary fibroblastic changes in rats subjected to an iodine deficient diet also support the association between the breast and thyroid. ${ }^{9}$

The possible interactions between thyroid gland and breast 
tissue are based on the common property of the mammary and thyroid epithelial cells to concentrate iodine by membrane active transport mechanisms, as well as the presence of TSH receptors in adipocytes, abundantly found in the breast tissue. ${ }^{1,12,13}$ The oxidation of iodine in the alveolar mammary cells uses lactoperoxidase, which is mechanistically similar to peroxidase in thyroid glands. ${ }^{6,14}$ Many in vitro studies have shown that increased thyroid hormone levels have actions similar to that of estrogen which promotes breast cancer proliferation and angiogenesis. ${ }^{15}$ Studies also show that the activation of thyroid receptors (TR) in breast tissue may stimulate lobular proliferation of breast tissue, an action similar to that of oestrogen. ${ }^{15,16}$ TR $\beta$ has shown to have positive prognostic factor for five year and overall survival in BRCA1 patients while TR $\alpha$ positivity predicted reduced five year survival. ${ }^{17}$ Recent studies have demonstrated that the increased prevalence of thyroid peroxidase antibodies (TPOAbs) in patients with breast cancer may have a protective role and decreasing levels of TPOAbs with increase in clinical stage. $^{18}$

Various observations have been reported with reference to sonographic changes in thyroid in breast carcinoma patients. An increased prevalence of non-toxic goiter was reported, by Giani et $\mathrm{al}^{1}$ in patients of breast carcinoma. Gogas $\mathrm{J}$ et $\mathrm{al}^{19}$ reported thyroid enlargement in $28.1 \%$ of breast carcinoma cases and the presence of nodules in $53 \%$ cases of breast carcinoma patients, while the control group patients had thyroid enlargement in $11.6 \%$ cases and nodular thyroid in $19.4 \%$ cases. Our study is consistent with these observations with $50 \%$ of study group patients having thyroid nodules as compared to $10 \%$ of cases in control group $(p<0.002)$. This observation correlates and documents an increased prevalence of thyroid enlargement in breast cancer patients.

The present study demonstrated an increased total thyroid volume in breast carcinoma group as compared to control group and an increase in total thyroid volume with increasing stage of breast carcinoma, although it was statistically insignificant $(\mathrm{p}=0.1)$. Smyth et $\mathrm{al}^{5}$ reported similar findings with thyroid enlargement reported in $41.5 \%$ of breast cancer patients compared to only $10.5 \%$ in controls $(\mathrm{p}<0.01)$. They also noted the mean thyroid volume of $21.1 \pm 1.4 \mathrm{ml}$ (median$16.7 \mathrm{ml}$ ) in the patients with breast cancer, which was significantly greater than that of $13.2 \pm 0.5 \mathrm{ml}$ (median$12.0 \mathrm{ml})$ in control patients $(\mathrm{p}<0.01)$. Similar to our study they also found the thyroid volume to increase with the stage of breast carcinoma. Other studies have demonstrated total thyroid volume measurement to be independently associated with prognosis in breast carcinoma along with other well established prognostic factors such as axillary nodal status or tumor size. $^{20}$ USG guided FNAC was done in study group patients with thyroid nodules on ultrasonography. The cytological examination showed benign nodular thyroid disease in all these cases. Turken et $\mathrm{al}^{21}$ reported similar findings with $64 \%(n=96 / 150)$ of breast cancer cases having benign thyroid disorders. Nio et $\mathrm{al}^{22}$ demonstrated that $2.4 \%$ cases of breast carcinoma had thyroid malignancies.

Mass screening for thyroid cancer has been more controversial than for other cancers and it is important to identify high risk patients to increase both the effectiveness and detection rates of screening methods. As previously reported, breast cancer has been implicated as a potential risk factor for thyroid cancer. ${ }^{23,24}$ Although not statistically significant, $16.4 \%$ of patients with a diagnosis of breast cancer were placed in the USG high risk group for thyroid cancer in a study by Chung et $\mathrm{al}^{25}$, compared with $5.8 \%$ of patients without breast cancer, thus demonstrating a possible association between breast cancer and thyroid cancer.

This study also had few limitations. The sample size in the present study consisted of 30 breast carcinoma patients and 20 control patients, which is a small number for having definite conclusion in this regard. So, a large multicentric trial study using USG guided FNAC, histopathological examination along with thyroid function status will be required to rule out thyroid lesions associated with breast carcinoma

\section{CONCLUSION}

In conclusion, the present study provides evidence for the existence of biological link between breast carcinoma and thyroid disorders. It supports ultrasonography as a better modality than clinical examination for screening of the thyroid gland in breast cancer patients to detect subtle changes and further evaluation even in solid nodules. The study recommends the scope of further evaluation of thyroid function status, thyroid auto antibodies and TSH receptors in breast tissue to establish the hypothesis.

\section{ACKNOWLEDGEMENTS}

The principal investigator of this study is Prof. Dr. Anand Kumar.

\section{REFERENCES}

1. Giani C, Fierabracci P, Bonacci R, et al. Relationship between breast cancer and thyroid disease: relevance of autoimmune thyroid disorders in breast malignancy. J Clin Endocrinol Metab 1996; 81:990-994.

2. Goldman MB. Thyroid diseases and breast cancer. Epidemiol Rev 1990; 12: 16-28.

3. Goldman MB, Monson RR, Maloof F. Cancer mortality in women with thyroid disease. Cancer Res 1990; 50: 2283-9. 
4. Moossa AR, Evans DA, Brewer AC. Thyroid status and breast cancer. Reappraisal of an old relationship. Ann R Coll Surg Engl 1973; 53: $178-88$

5. Smyth PP, Smith DF, McDermott EW, et al. A direct relationship between thyroid enlargement and breast cancer. J Clin Endocrinol Metab 1996; 81: 937-941.

6. Weng $\mathrm{C}-\mathrm{H}$, Chen $\mathrm{Y}-\mathrm{H}$, Lin $\mathrm{C}-\mathrm{H}$, et al. Thyroid disorders and breast cancer risk in Asian population: a nationwide populationbased case-control study in Taiwan. BMJ Open 2018; 8: e020194.

7. Brown MC, Spencer R. Thyroid gland volume estimated by use of ultrasound in addition to scintigraphy. Acta Radiol Oncol Radiat Phys Biol 1978; 17:337-41.

8. Beatson GT. On the Treatment of Inoperable Cases of Carcinoma of the Mamma: Suggestions for a New Method of Treatment, with Illustrative Cases. Trans Medico-Chirurgical Soc Edinburgh 1896; 15: 153-179.

9. Kurland LT, Annegers JF. Breast cancer and Hashimoto Thyroiditis. Lancet 1976; 307: 808.

10. Lemaire M, Baugnet-Mahieu L. Thyroid function in women with breast cancer. Eur J Cancer Clin Oncol 1986; 22: 301-7.

11. Mittra I, Perrin J, Kumaoka S. Thyroid and other autoantibodies in British and Japanese women: an epidemiological study of breast cancer. Br Med J 1976; 1: 257-9.

12. Davies TF. The thyrotropin receptors spread themselves around. J Clin Endocrinol Metab 1994; 79: 1232-1233.

13. Dong L, Lu J, Zhao B, et al. Review of the possible association between thyroid and breast carcinoma. World J Surg Oncol 2018; $16: 130$

14. Fierabracci P, Pinchera A, Campani D, et al. Association between breast cancer and autoimmune thyroid disorders: no increase of lymphocytic infiltrates in breast malignant tissues. J Endocrinol Invest 2006; 29: 248-251.

15. Conde I, Paniagua R, Zamora J, et al. Influence of thyroid hormone receptors on breast cancer cell proliferation. Ann Oncol 2006; 17: 60-64.

16. González-Sancho, José M, Garcı V, et al. Thyroid hormone receptors/THR genes in human cancer. Cancer Lett 2003; 192: $121-132$.

17. Heublein S, Mayr D, Meindl A, et al. Thyroid Hormone Receptors Predict Prognosis in BRCA1 Associated Breast Cancer in Opposing Ways. PLoS One 2015; 10: e0127072.

18. Godlewska M, Arczewska KD, Rudzińska M, et al. Thyroid peroxidase (TPO) expressed in thyroid and breast tissues shows similar antigenic properties. PLoS One 2017; 12: e0179066.

19. Gogas J, Kouskos E, Tseleni-Balafouta S, et al. Autoimmune thyroid disease in women with breast carcinoma. Eur J Surg Oncol 2001; 27: 626-630
20. Smyth P, Shering S, Kilbane M, et al. Serum Thyroid Peroxidase Autoantibodies, Thyroid Volume, and Outcome in Breast Carcinoma 1. J Clin Endocrinol Metab 1998; 83: 2711-2716.

21. Turken O, NarIn Y, DemIrbas S, et al. Breast cancer in association with thyroid disorders. Breast Cancer Res 2003; 5: R110.

22. Nio $\mathrm{Y}$, Iguchi $\mathrm{C}$, Itakura $\mathrm{M}$, et al. High incidence of synchronous or metachronous breast cancer in patients with malignant and benign thyroid tumor or tumor-like disorders. Anticancer Res 2009; 29: 1607-10.

23. Smyth PP. The thyroid and breast cancer: a significant association? Ann Med 1997; 29: 189-91.

24. Vassilopoulou S, Palmer L, Taylor S, et al. Incidence of breast cancer in women with thyroid carcinoma. Cancer 1999; 85: 696-705.

25. Chung WY, Chang HS, Kim EK, et al. Ultrasonographic Mass Screening for Thyroid Carcinoma: A Study in Women Scheduled to Undergo a Breast Examination. Surg Today 2001; 31:763-767. 